\title{
PENGELOLAAN PARIWISATA BAHARI BERBASIS COMMUNITY-BASED TOURISM DALAM PENINGKATAN EKONOMI MASYARAKAT PESISIR
}

\author{
Rullyana Puspitaningrum Mamengko ${ }^{1}$, dan Erlina Daru Kuntari \\ ${ }^{1}$ Universitas Negeri Yogyakarta, Yogyakarta, Indonesia, Email: rullyana.mamengko@uny.ac.id \\ ${ }^{2}$ Akademi Pariwisata Buana Wisata Yogyakarta, Yogyakarta, Indonesia, Email: erlina@akparbuanawisata.ac.id
}

\begin{tabular}{|c|}
\hline \\
\hline Histori Artikel \\
Submitted: \\
11 Desember 2019 \\
Reviewed: \\
10 Januari 2020 \\
Accepted: \\
10 Februari 2020 \\
Published: \\
15 Mei 2020 \\
\hline
\end{tabular}

\begin{abstract}
ABSTRAK
Tujuan dari penelitian ini adalah untuk mengetahui pentingnya pengelolaan pariwisata bahari berbasis pemberdayaan masyarakat (Community-Based Tourism) dalam meningkatkan pendapatan ekonomi masyarakat pesisir di wilayah pesisir Pantai Utara Jawa Tengah. Penelitian ini merupakan penelitian deskriptif kualitatif dengan prosedur penelitian yaitu tahap deskripsi, tahap reduksi, dan tahap seleksi. Lokasi penelitian di wilayah pesisir Pantai Utara Jawa Tengah dengan responden yang dipilih secara acak. Hasil penelitian yang diperoleh yaitu adanya multiplayer effect pelibatan masyarakat dalam pengelolaan pariwisata bahari di wilayah pesisir yang meliputi pendapatan masyarakat meningkat, terserapnya tenaga kerja lokal,
\end{abstract} terbukanya ruang usaha bagi masyarakat lokal, terpeliharanya lingkungan sekitar, dan perbaikan amenitas pendukung lainnya.

Kata Kunci: Pariwisata bahari, community-based tourism, ekonomi masyarakat

\section{MANAGEMENT OF MARINE TOURISM BASED ON COMMUNITY-BASED TOURISM IN INCREASING REVENUE OF COASTAL COMMUNITIES}

\begin{abstract}
The economic conditions of the coastal communities of the North Coastal of Central Java, for several decades, have been categorized as not having adequate livelihoods, even though Indonesia's marine resources are relatively abundant. The purpose of this study was to determine the importance of managing marine tourism based on community-based tourism in increasing revenue of coastal communities in the north coastal of Central Java. This research is a qualitative descriptive study, with research procedures namely the description stage, the reduction stage, and the selection stage. Respondents in this study were 56 respondents who were randomly selected in each City or Regency. Respondents consisted of the Tourism Office, Pokdarwis or Bumdes, workers in tourist destinations, community leaders, sellers at a tourist destinations, and visitors. The results obtained have a multiplier effect, i.e. increasing revenue of coastal communities, absorption of workforce from local communities, opportunity of open up business space for local communities, preservation cleanliness and nature the environment to supports sustainable tourism, and also the benefits received by the community around the tourist destination regarding regional development, improvement of road and bridge infrastructure, improvement of public facilities such as places of worship and other public facilities.
\end{abstract}

Keywords : Marine tourism, community-based tourism, economic 


\section{PENDAHULUAN}

Indonesia merupakan negara kepulauan terbesar di dunia. Indonesia memiliki 17.506 pulau dan pantai sepanjang $81.000 \mathrm{~km}$, serta laut seluas 5,8 juta $\mathrm{km}^{2}$. Potensi yang besar tersebut seharusnya dapat memberikan sumber penghidupan yang layak. Namun pada kenyataannya, kualitas hidup masyarakat masih tergolong rendah. Untuk itu, dibutuhkan peran pemerintah dalam menentukan arah pembangunan daerah (Noer, 2018).

Perencanaan hendaknya dilakukan secara integral dan holistik dengan melibatkan masyarakat lokal sehingga masyarakat dapat memperoleh manfaat ekonomi sekaligus sumber daya alamnya dapat terjaga. Tindakan yang dapat diselaraskan dengan hal tersebut di atas adalah pemberdayaan masyarakat dalam mengelola pariwisata daerah atau lebih dikenal dengan communitybased tourism.

Pendekatan pembangunan pariwisata yang menempatkan masyarakat sebagai bagian yang tidak terpisahkan dari produk wisata merupakan esensi dari pembangunan yang berbasis pemberdayaan masyarakat (Adikampana, 2017). Pendekatan ini memiliki nilai strategis yaitu mampu menciptakan produk wisata yang bercirikan budaya setempat. Pariwisata jika dikelola dengan baik maka akan memberikan kontribusi ekonomi secara langsung kepada masyarakat di sekitar daerah pariwisata. Sehingga secara tidak langsung, pariwisata memberikan kontribusi signifikan pada pendapatan asli daerah (PAD) dan pertumbuhan ekonomi masyarakat di daerah (Rusyidi \& Fedryansah, 2018).

Kondisi masyarakat pesisir merupakan kelompok masyarakat yang relatif tertinggal secara ekonomi, sosial (khususnya dalam hal akses pendidikan dan layanan kesehatan), dan kultural dibandingkan dengan kelompok masyarakat lain (Fatmasari, 2014). Masyarakat pesisir, terutama nelayan lekat dengan kemiskinan bahkan disebut kelompok miskin diantara yang miskin (Sipahelut, 2010). Menurut hasil penelitian Widodo
(2011) tentang faktor penyebab kemiskinan masyarakat pesisir di Kwanyar Barat, Kabupaten Bangkalan adalah rendahnya akses terhadap modal terutama modal finansial sehingga menyebabkan nelayan tidak mampu mengakses modal fisik berupa teknologi penangkapan yang lebih modern. Ketimpangan juga merupakan salah satu permasalahan penyebab kemiskinan. Hal ini, berkaitan dengan keuntungan ekonomi dari pemanfaatan sumber daya pesisir dan laut, baru dinikmati oleh kelompok masyarakat tertentu seperti juragan kapal dan pengusaha perikanan, namun belum dapat dinikmati oleh masyarakat pesisir dan nelayan. Selain kesenjangan dalam pendapatan, kesenjangan dalam kepemilikan justru menjadi permasalahan yang lebih serius (Syarief, 2001). Kondisi ini juga terjadi di wilayah pesisir Pantai Utara Jawa Tengah, kondisi masyarakatnya, sebagian besar masih berada di bawah garis kemiskinan.

Jawa Tengah adalah sebuah provinsi di Indonesia yang terletak di bagian tengah Pulau Jawa. Ibu kotanya adalah Semarang. Luas wilayah Jawa Tengah adalah 32.548 $\mathrm{km}^{2}$, atau sekitar $28,94 \%$ dari luas Pulau Jawa. Jawa Tengah memiliki 29 kabupaten dan 6 kota. Panjang pantai Jawa Tengah kurang lebih $251 \mathrm{~km}$ (Peta Laut DISHIDROS TNI AL, 2013) dan terdapat 10 kabupaten dan 3 kota yang berbatasan langsung dengan Laut Jawa, yang dalam penelitian ini disebut wilayah pesisir pantai utara Jawa Tengah. Kabupaten dan Kota tersebut adalah Kabupaten Brebes, Kabupaten Tegal, Kota Tegal, Kabupaten Pemalang, Kabupaten Pekalongan, Kota Pekalongan, Kabupaten Batang, Kabupaten Kendal, Kota Semarang, Kabupaten Demak, Kabupaten Jepara, Kabupaten Pati, dan Kabupaten Rembang.

Penelitian ini memiliki urgensi yaitu dapat mengetahui cara peningkatan pendapatan ekonomi masyarakat wilayah pesisir yang saat ini masih termasuk kategori masyarakat berpendapatan rendah, dengan cara mengembangkan pariwisata bahari berbasis pemberdayaan masyarakat, sehingga masyarakat dapat ikut merencanakan, 
mengelola, memanfaatkan, dan memelihara potensi sumber daya alamnya untuk mewujudkan pariwisata yang berkelanjutan (sustainable tourism).

\section{LITERATUR REVIEW}

\section{Community-Based Tourism}

Hiariey (2013) menemukan bahwa strategi meningkatkan peran aktif masyarakat dalam pengelolaan wilayah pesisir adalah dengan pengelolaan wilayah pesisir berbasis masyarakat (co-management). Dalam strategi tersebut, masyarakat memiliki kewenangan cukup dalam pengelolaan dan terakomodasinya kepentingan masyarakat dalam proses pengelolaan. Sebagaimana disampaikan Ticoalu et al. (2013) bahwa keberhasilan program karena masyarakat, pemerintah dan pengusaha memiliki kontribusi yang relatif sama terhadap moral, ditinjau dari pemberdayaan masyarakat pesisir.

Menurut Tulungen (2001), pendekatan pengelolaan sumberdaya wilayah pesisir yang dapat menjadi rujukan adalah berbasis pemberdayaan masyarakat. Konsep ini telah menjadi pendekatan utama dalam pengelolaan sumberdaya pesisir di Indonesia sebagai bagian dari sistem pemerintahan yang desentralistis. Program yang melibatkan pemberdayaan masyarakat di bidang pengelolaan pariwisata disebut Community Based-Tourism (CBT).

\section{Community-Based Tourism}

(CBT)

merupakan suatu pendekatan pembangunan pariwisata yang menekankan pada pemberian kesempatan kepada masyarakat lokal untuk ikut berkontribusi dalam manajemen perencanaan dan pengelolaan pariwisata setempat, melalui kehidupan yang lebih demokratis, termasuk dalam pembagian keuntungan dari kegiatan pariwisata yang lebih adil bagi masyarakat (Adikampana, 2017). Pendekatan ini membutuhkan support dari pemerintah agar bersama-sama dengan masyarakat meningkatkan dan mengembangkan pembangunan guna mencapai kesejahteraan bersama.

Seperti hasil penelitian Mardjoeki (2012) yang menyatakan bahwa pemberdayaan masyarakat pesisir perlu adanya kerja sama yang simultan dan lintas sektoral, pendekatan yang paling sesuai dengan kondisi tersebut adalah dengan cara pendekatan partisipatif yaitu suatu pendekatan yang melibatkan kerja sama antara masyarakat setempat dan pemerintah. Kemudian Fitriansah (2012) dalam hasil penelitiannya juga mengemukakan bahwa keberhasilan pemberdayaan di pesisir adalah karena adanya penyadaran kepada masyarakat bahwa program yang mereka jalankan bukan semata-mata program dari pemerintah, tetapi juga menjadi program mereka sendiri. Terdapat tiga aktor yang memainkan perannya dengan sempurna yakni: pemerintah daerah sebagai pembina dan pengarah program, masyarakat lokal sebagai pelaksana utama seluruh kegiatan dan kelompok yang memfasilitasi hubungan kedua aktor secara transparansi dan terbuka.

Senada dengan hal tersebut, Wearing (Dewi, 2013) menyatakan bahwa masyarakat lokal berperan sebagai tuan rumah dan menjadi pelaku penting dalam pengembangan desa wisata, dalam keseluruhan tahapan mulai tahap perencanaan, pengawasan dan implementasi. Artinya masyarakat lokal memiliki kedudukan yang sama penting dengan pemerintah dan swasta sebagai salah satu pemangku kepentingan dalam pengembangan pariwisata, seperti ditunjukkan pada gambar 1. 


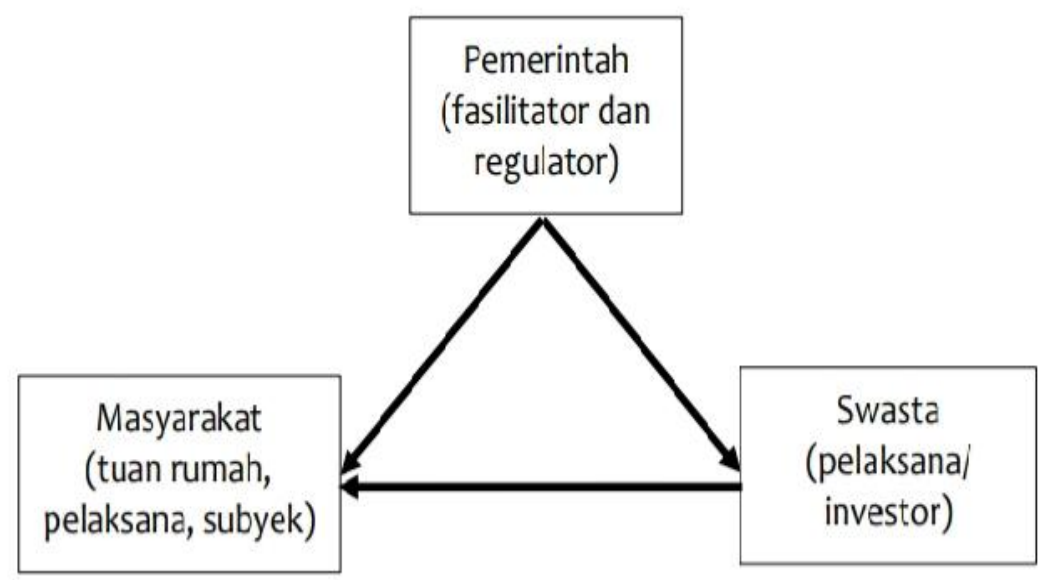

Gambar 1. Pemangku Kepentingan dalam Pengembangan Pariwisata Sumber: Wearing (Dewi, 2013)

\section{Pengelolaan Pariwisata Community-Based Tourism}

Kunci pengaturan pembangunan pariwisata berbasis Community-Based Tourism, meliputi beberapa hal, yaitu: (1) Adanya dukungan pemerintah; (2) Partisipasi dari stakeholder; (3) Pembagian keuntungan yang adil; (4) Penggunaan sumber daya lokal secara berkesinambungan; (5) Penguatan institusi lokal; (6) Keterkaitan antara level regional dan nasional (Pantiyasa, 2011).

Selanjutnya, perspektif pengelolaan wilayah pesisir dapat didasarkan kepada otonomi daerah dengan guideline sebagai berikut: (1) Secara ekologis haruslah dapat menjamin kelestarian sumber daya pesisir; (2) Secara ekonomi dapat mendorong dan meningkatkan taraf hidup masyarakat serta meningkatkan pertumbuhan ekonomi daerah dengan tetap mempertahankan stabilitas produktivitas sumber daya pesisir; (3) Secara sosial budaya memberikan ruang bagi kearifan lokal dan pemberdayaan masyarakat serta meningkatkan keterlibatan partisipasi masyarakat dalam kebijakan dan pembangunan; (4) Secara kelembagaan dan hukum dapat menjadi payung dalam pengelolaan sumber daya pesisir dan menjamin tegaknya hukum serta penguatan kelembagaan; (5) Dalam bidang pertahanan dan keamanan sebagai garda terdepan dalam mewaspadai potensi-potensi yang akan mengganggu pertahanan dan keamanan baik di perairan maupun Zona Ekonomi Eksklusif, terutama dalam menjaga sumber daya pesisir dan kelautan (Masyhudzulhak, 2011).

Terkait dengan hal tersebut, perlu dilakukan pelibatan masyarakat dalam pengelolaan komponen-komponen pengembangan pariwisata yang secara garis besar diklasifikasikan sebagai berikut: (1) Atraksi dan aktivitas pariwisata; (2) Akomodasi; (3) Fasilitas dan jasa layanan wisata lainnya; (4) Fasilitas dan jasa layanan transportasi; (5) Infrastruktur lainnya, seperti air, listrik, dan telekomunikasi; (6) Elemen institusional, (Hadiwijoyo, 2012). Selaras dengan yang diungkapkan oleh Yoeti (2008) bahwa terdapat 3 (tiga) faktor yang dapat menentukan keberhasilan pengembangan pariwisata sebagai suatu industri, yaitu: tersedianya objek atraksi wisata, adanya fasilitas aksesibilitas, dan bernilai untuk dikunjungi atau dilihat (Hadiwijoyo, 2012).

Dalam pengelolaan obyek wisata, hendaknya mencakup 6 (enam) hal dasar, yaitu: (1) Pembinaan produk wisata, (2) Pembinaan masyarakat wisata, (3) Pemasaran terpadu, (4) Paduan penyebaran, (5) Paduan komunikasi, dan (6) Paduan pelayanan, (Yoeti, 2008).

\section{Pengelolaan Pariwisata Bahari}

Dalam praktiknya, pengelolaan pariwisata bahari perlu memperhatikan hal-hal sebagai berikut: (1) Pengembangan wisata bahari harus mengikuti kaidah-kaidah pembangunan berkelanjutan yang berwawasan lingkungan; 
(2) Pengembangan wisata bahari diarahkan pada pola pengembangan ekowisata atau wisata ramah lingkungan yang mengupayakan pemanfaatan lingkungan alam bahari sekaligus juga menyelamatkan lingkungan alam bahari tersebut; (3) Pengembangan wisata bahari harus ditujukan pada upaya meningkatkan pemerataan kesempatan, pendapatan, peran serta, dan tanggung jawab masyarakat setempat yang terpadu dengan pemerintah dan dunia usaha (Prasiasa dan Hermawan, 2012).

Selanjutnya, pengembangan wisata bahari harus mengacu pada strategi pengembangan sebagai berikut: (1) Menjadikan prinsipprinsip ecotourism sebagai payung pembangunan wisata bahari; (2) Membangun kemitraan antar pelaku, yang lebih bersifat tidak struktural, namun lebih mengarah ke fungsional; (3) Pengembangan diversifikasi kegiatan dan daya tarik wisata maupun produk seni budaya etnis yang dapat dijadikan daya tarik wisata; (4) Mengembangkan ketertarikan dan komplementaritas antar wilayah dalam suatu sistem tata ruang pengembangan pariwisata yang terkait dengan sektor-sektor lain; (5) Mendorong kerjasama bilateral dan multilateral antar negara luar dengan pemerintah daerah (pemda) setempat dan antar daerah terutama dalam pengembangan wisata bahari dan kegiatan lain termasuk keamanan dan keselamatan kegiatan wisata bahari lintas negara dan daerah (Prasiasa dan Hermawan, 2012).

\section{METODE}

Artikel ini merupakan hasil penelitian kualitatif, penelitian kualitatif dilaksanakan untuk membangun pengetahuan melalui pemahaman dan penemuan. Pendekatan kualitatif adalah suatu proses penelitian dan pemahaman yang berdasarkan pada metode yang menyelidiki suatu fenomena sosial dan masalah manusia (Iskandar, 2009). Peneliti membuat suatu gambaran kompleks, meneliti kata-kata, laporan terinci dari pandangan responden, serta melakukan studi pada situasi yang alami.

Tahapan pelaksanaan penelitian yang digunakan terbagi dalam 5 (lima) tahap yaitu: (1) merumuskan masalah sebagai fokus penelitian; (2) mengumpulkan data di lapangan; (3) menganalisis data; (4) merumuskan hasil studi; (5) menyusun rekomendasi untuk pembuatan keputusan (Danim \& Darwis, 2003). Selaras dengan hal tersebut, pengolahan datanya dilakukan melalui 3 (tiga) prosedur yaitu sebagai berikut: deskripsi, reduksi, dan seleksi data.

Data primer diperoleh dari hasil wawancara di lapangan dan observasi. Kemudian data sekunder diperoleh dari peraturan setempat, data statistik dari dinas terkait, dan dokumentasi yang terdapat di masing-masing responden. Metode pengumpulan data melalui wawancara dengan menggunakan daftar pertanyaan dan wawancara secara mendalam (in depth interview). Observasi dilakukan untuk mengamati hasil program pemberdayaan masyarakat yang sudah dilakukan, kelembagaannya, serta relasi sosial budaya masyarakat. Responden dalam penelitian ini adalah 56 responden yang dipilih secara acak di masing-masing Kota atau Kabupaten. Responden terdiri dari Dinas Pariwisata, Kelompok Sadar Wisata (Pokdarwis) atau Badan Usaha Milik Desa (Bumdes), pekerja di destinasi wisata, tokoh masyarakat, pedagang/ pemilik kios di destinasi wisata, dan pengunjung atau wisatawan.

Adapun kerangka berpikir dalam penelitian ini diilustrasikan dalam gambar 2 berikut ini. 


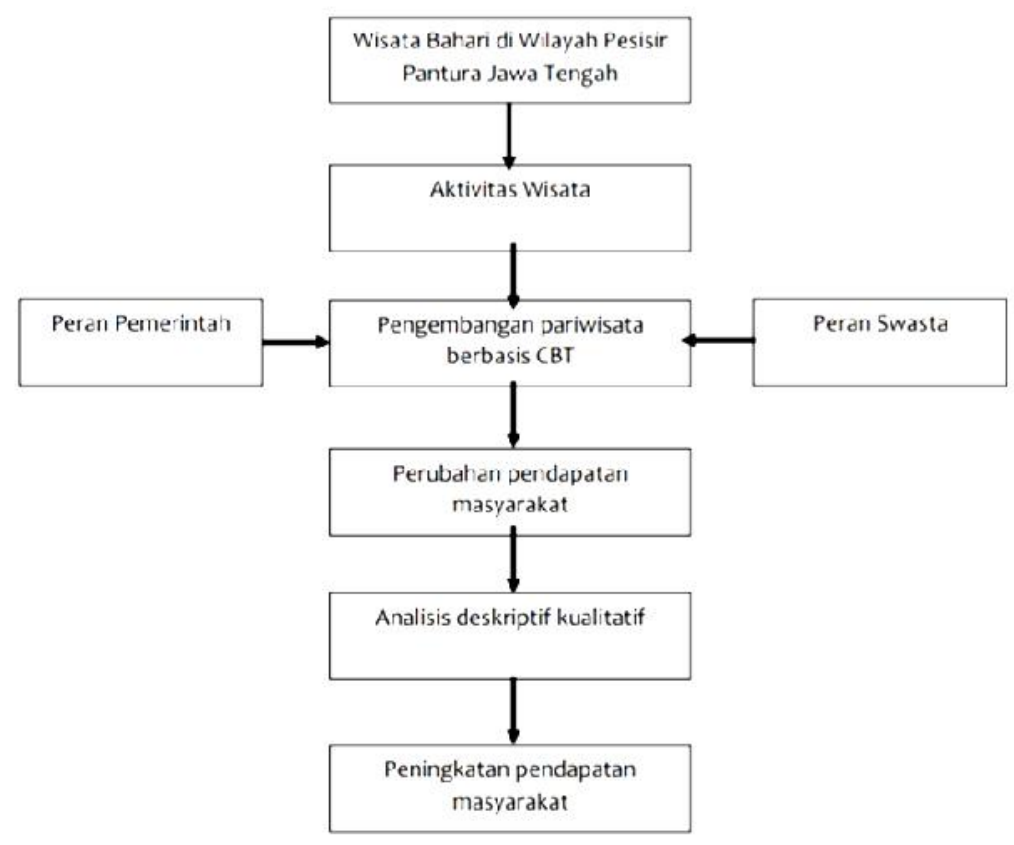

Gambar 2. Road Map Penelitian

Selanjutnya prosedur pengolahan data, Yang dimaksud dengan wilayah pesisir melalui 3 (tiga) tahap utama yaitu: tahap pantai utara Jawa Tengah adalah wilayah deskripsi, tahap reduksi, dan tahap seleksi.

\section{HASIL DAN PEMBAHASAN}

Gambaran Umum Wilayah Pesisir Pantai Utara Jawa Tengah yang berbatasan langsung dengan Laut Jawa. Wilayah tersebut meliputi: bagian utara dari Kabupaten Brebes, Kota dan Kabupaten Tegal, Kabupaten Pemalang, Kota dan Kabupaten Pekalongan, Kabupaten Batang, Kabuaten Kendal, Kota Semarang, Kabupaten Demak, Kabupaten Jepara, Kabupaten Pati dan Kabupaten Rembang.

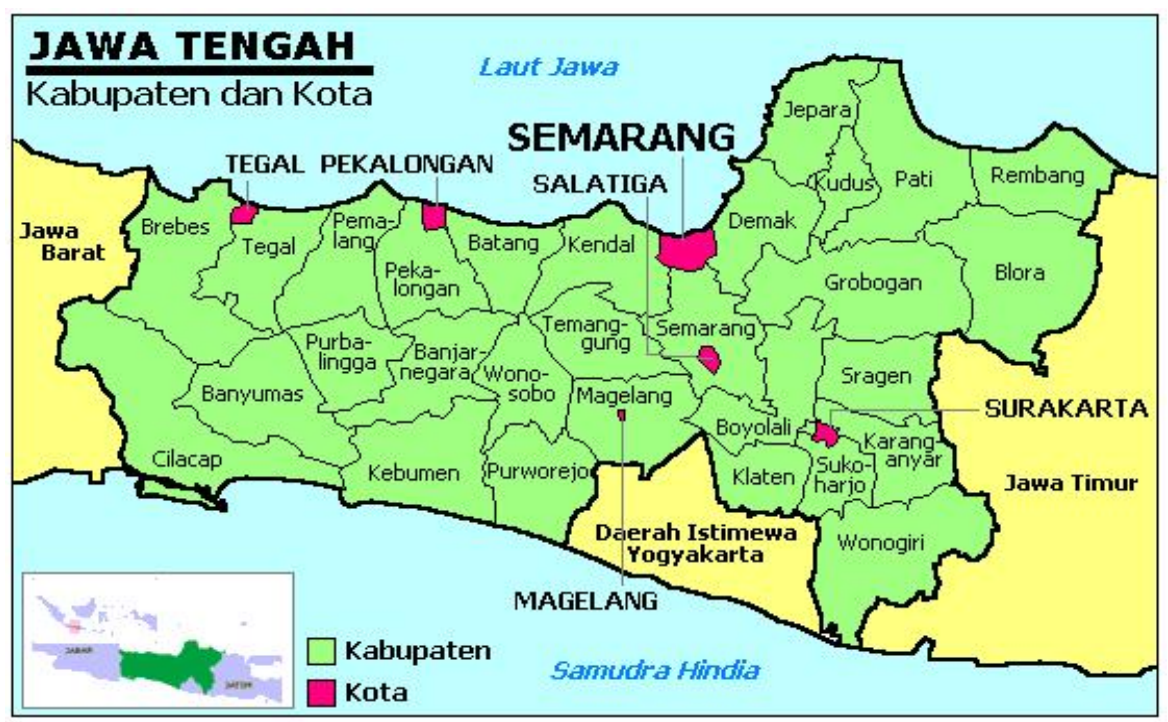

Gambar 3. Peta Administratif Jawa Tengah Sumber: google.com Peta Administratif Jawa Tengah 
Sebagian besar masyarakat pantai utara Jawa Tengah memiliki mata pencaharian sebagai nelayan, selain itu sebagai petani atau pedagang. Para nelayan biasanya langsung menjual ikan tangkapannya ke pedagang ikan di Tempat Pelelangan Ikan (TPI) yang terletak di masing-masing wilayah, baru kemudian oleh pedagang ikan akan langsung dijual ke pembeli dalam bentuk ikan segar maupun diolah terlebih dahulu menjadi ikan asin, ikan asap, atau olahan ikan lainnya. Selain sebagai nelayan, mata pencaharian lainnya masyarakat pesisir adalah sebagai petani.

Masyarakat pantai utara Jawa Tengah umumnya membudidayakan tanaman hortikultura seperti sayur mayur maupun buah-buahan, dan juga bunga melati. Seperti yang diungkapkan oleh salah satu narasumber di pedukuhan Pantairejo, Desa Wonokerto, Kabupaten Pekalongan bahwa mata pencaharian utama di dukuh tersebut dahulunya adalah petani melati, karena menanam melati itu untungnya besar. Sekali tanam untuk jangka waktu 5 tahun, 1 tahun pertama merawat tanaman melati, 4 tahun selanjutnya untuk panen dan setiap hari memetik melati untuk dijual ke pasar sehingga masyarakat mendapatkan penghasilan setiap harinya. Karena di pesisir Pantai Utara Jawa Tengah sering terjadi banjir rob, bahkan pernah terjadi banjir rob yang tinggi hingga mencapai ladang melati warga, menyebabkan banyak tanaman melati dan hortikultura mati. Lebih parahnya lagi, setelah banjir rob surut, tanahnya tidak dapat lagi digunakan untuk bercocok tanam karena banjir rob membawa pasir ke daratan dan menimbun ladang warga tersebut. Dengan kondisi demikian, maka masyarakat harus memikirkan alternatif lain untuk memenuhi kebutuhannya sehari-hari.

Hal yang sama juga diungkapkan oleh hasil penelitian dari Manumono (2008) yang menyatakan bahwa abrasi tambak dan rob menyebabkan penurunan pendapatan petani tambak dan nelayan sehingga mereka mengalami perubahan perilaku yang bersifat negatif yaitu apriori, apatis dan mengalami gangguan jiwa. Sebagian petani dan nelayan yang hilang tambaknya beralih menjadi buruh serabutan, nelayan seser ataupun nelayan tangkap (sampan dan jaring), yang sebelumnya juragan berubah menjadi petani penggarap.

Dari kondisi tersebut, maka alternatif mata pencaharian yang dipahami oleh masyarakat adalah kembali melaut (nelayan) atau menjadi pedagang. Masih sedikit masyarakat yang berpikiran untuk mengembangkan daerahnya dengan cara memaksimalkan potensi yang ada, kemudian mengelolanya menjadi mata pencaharian alternatif. Hal ini dikarenakan sifat dari masyarakat pesisir yang lebih menyukai mendapatkan uang secara cepat, namun cepat pula membelanjakannya. Sedangkan untuk membangun atau mengelola daerah pesisir menjadi destinasi yang bisa memberikan mata pencaharian, pasti akan memerlukan waktu yang tidak sebentar.

Terdapat ekosistem terumbu karang dan pohon-pohon bakau/ mangrove di sepanjang Pantura yang berfungsi untuk menangkis gelombang pasang yang dapat menyebabkan abrasi. Hal ini dapat menjadi potensi yang dapat dikembangkan menjadi wisata konservasi pantai atau wisata hutan mangrove. Saat ini, potensi pengembangan wisata ini mulai diminati oleh masyarakat, karena adanya beberapa contoh wisata pantai yang telah berhasil dikelola oleh masyarakat, misalnya: Wisata Mangrove Tapak di Semarang, Maron Mangrove Edupark di Semarang, Puri Maerokoco di Semarang, Hutan Mangrove Mintaragen di Tegal, Wisata Mangrove Park di Pekalongan, dan Jembatan Merah Hutan Mangrove di Rembang.

Wisata hutan bakau atau mangrove sudah semakin diminati oleh pengunjung dengan adanya paket-paket wisata yang menarik misalnya wisata susur sungai dengan perahu sekaligus kuliner hasil laut dengan melihat pemandangan mangrove.

Melihat peluang ini, maka perlu dilakukan sosialisasi kepada masyarakat Pantai Utara Jawa Tengah (Pantura) yang masih belum 
mengembangkan daerahnya untuk dapat mengikuti jejak masyarakat pesisir di daerah lain yang telah berhasil mengembangkan daerahnya, sehingga masyarakat memiliki alternatif mata pencaharian untuk dapat memenuhi kebutuhannya sehari-hari.

\section{Penerapan Sapta Pesona sebagai Perwujudan Program Pemberdayaan Masyarakat}

Peningkatan peran masyarakat dalam pembangunan kepariwisataan memerlukan berbagai upaya pemberdayaan (empowerment) agar masyarakat dapat berperan lebih aktif dan optimal serta sekaligus menerima manfaat positif dari kegiatan pembangunan yang dilaksanakan untuk meningkatkan kesejahteraannya. Pemberdayaan masyarakat dalam konteks pembangunan kepariwisataan dapat didefinisikan yaitu upaya penguatan dan peningkatan kapasitas, peran, dan inisiatif masyarakat sebagai salah satu pemangku kepentingan, untuk dapat berpartisipasi dan berperan aktif sebagai subjek atau pelaku maupun sebagai penerima manfaat dalam pengembangan kepariwisataan secara berkelanjutan. (Renstra Dit. Pemberdayaan Masyarakat, 2010).
Masyarakat sebagai subyek atau pelaku pembangunan berarti bahwa masyarakat menjadi pelaku penting yang terlibat secara aktif dalam proses perencanaan, pengembangan kepariwisataan, bersamasama dengan pemerintah dan swasta. Masyarakat sebagai penerima manfaat berarti masyarakat diharapkan dapat memperoleh nilai manfaat ekonomi yang berarti dari pengembangan kegiatan kepariwisataan untuk meningkatkan kualitas hidup dan kesejahteraan sosial masyarakat yang bersangkutan.

Salah satu aspek yang mendasar bagi keberhasilan pembangunan kepariwisataan adalah terciptanya lingkungan yang kondusif yang mendorong tumbuh dan berkembangnya kegiatan kepariwisataan di suatu wilayah. Salah satunya adalah dengan perwujudan Sadar Wisata di kalangan masyarakat, yang meliputi 7 (tujuh) unsur pesona yaitu: Aman, Tertib, Bersih, Sejuk, Indah, Ramah, dan Kenangan (Karim, Kusuma, \& Amalia, 2017). Gambaran posisi dan peran penting Kelompok Sadar Wisata (Pokdarwis) dikaitkan dengan pengembangan kepariwisataan dapat diilustrasikan pada gambar 5 berikut ini.

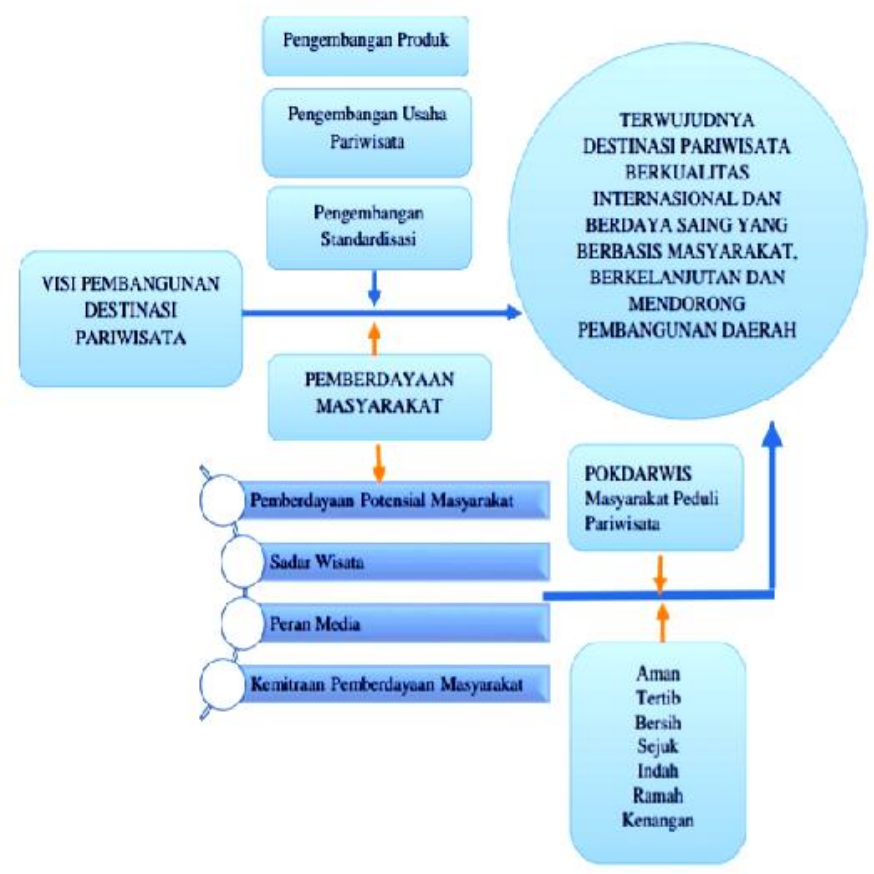

Gambar 4. Posisi dan Peran Penting Pokdarwis dalam Pengambangan Kepariwisataan 
Dari beberapa pantai yang telah peneliti kunjungi di Kabupaten Tegal, Kota Tegal, Kabupaten Pekalongan, Kota Pekalongan, Kota Semarang, dan Kabupaten Rembang, hanya Karangjahe Beach yang terletak di Kabupaten Rembang yang kegiatan Pokdarwisnya telah memenuhi penerapan semua unsur Sapta Pesona. Hal ini terbukti dengan adanya visi yang jelas yaitu "Pemberdayaan Masyarakat Lokal", serta adanya struktur organisasi serta tugas pokok dan fungsi yang jelas dari para anggotanya. Struktur organisasi Pokdarwis Karang Jahe terdiri dari: Pembina, Penasehat, dan Pengurus Harian. Kemudian Pengurus Harian dikelompokkan lagi menjadi Ketua, Wakil Ketua, Sekretaris, Bendahara, dan Anggota yang merupakan seksi dari masing-masing bidang.

Dari beberapa destinasi wisata pantai yang dikunjungi dalam 6 (enam) Kota dan Kabupaten di pesisir Pantai Utara Jawa Tengah, baru ada 1 (satu) Pokdarwis yang menerapkan Sapta Pesona secara lengkap, yaitu Pokdarwis Karang Jahe. Pokdarwis yang lainnya, ada yang menerapkan sebagian Sapta Pesona, bahkan ada yang sama sekali tidak menerapkannya karena permasalahan internal dari Pokdarwis sendiri seperti visi misi yang tidak jelas, pembagian kerja yang tidak jelas, tidak adanya struktur organisasi, bahkan sistem upah yang masih tidak jelas. Dari hasil keseluruhan observasi, peneliti menyampaikan contoh penerapan Sapta Pesona yang baik dan telah dilakukan oleh Pokdarwis Karang Jahe, sebagai berikut.

Aman. Adanya petugas keamanan yang bertugas selama pantai Karang Jahe menerima pengunjung yaitu dari jam 06.00 hingga waktu magrib setempat. Keamanan ini meliputi area parkir motor dan mobil yang aman, keamanan pengunjung dan barangbarang bawaan, keamanan bagi pengunjung yang hendak mandi-mandi atau bermain air di tepi laut.

Tertib. Ketertiban dilihat dari beberapa aspek yaitu petugas penjaga pantai, petugas tiket, petugas keamanan, dan petugas kebersihan yang selalu ada dan siap apabila dibutuhkan. Kemudian dilihat dari pengaturan dan pengelolaan parkir baik parkir sepeda motor maupun parkir mobil yang tertata dengan tertib dan rapi. Selanjutnya ketertiban dalam penataan dan pengelolaan kios-kios pedagang. Termasuk syarat bahwa setiap KK hanya diperbolehkan memiliki paling banyak 2 kios untuk berjualan, hal ini dalam rangka pemerataan dengan seluruh penduduk Desa Punjulharjo, sehingga bagi penduduk yang memiliki modal besar, tidak serta merta menguasai lahan untuk membuka beberapa kios sekaligus.

Bersih. Kebersihan menjadi poin utama yang menjadi perhatian Pokdarwis Karang Jahe. Mereka memahami bahwa kebersihan akan meningkatkan tingkat kenyamanan pengunjung yang akan berdampak pada bertambahnya jumlah kunjungan wisatawan maupun bertambahnya jumlah pengunjung yang loyal. Untuk itu, setiap ada event, petugas kebersihan selalu membersihkan area setelah selesai event sehingga pagi harinya kondisi area Karang Jahe sudah bersih dan siap menerima pengunjung. Pada hari biasa, terdapat pula tim kebersihan yang membersihkan area pantai dan telah bekerjasama dengan Dinas Lingkungan Hidup untuk pengadaan bak sampah yang terpisah dan ada pihak yang secara rutin mengambil sampah-sampah tersebut. Disamping itu, pembinaan kebersihan juga selalu disosialisasikan ke pedagang-pedagang di kios-kios untuk bertanggung jawab terhadap kebersihan di area kiosnya masingmasing. Serta adanya himbauan ke pengunjung untuk selalu membuang sampah pada tempatnya.

Sejuk. Kerja sama dengan PT Djarum dalam hal penghijauan area sekitar pantai dan pendampingan dalam hal penanaman maupun pemeliharaan. Hal ini pula sebagai salah satu bentuk bakti sosial yang dilakukan oleh PT Djarum.

Indah. Penataan kios-kios yang tertata rapi, adanya gazebo-gazebo, tempat-tempat duduk bagi pengunjung, wahana bermain, fasilitas perahu hias, pohon-pohon cemara laut yang 
teduh, melengkapi keindahan pemandangan wisata pantai yang dapat membuat pengunjung betah berkunjung ke pantai Karang Jahe.

Ramah. Keramahan adalah energi utama dalam pariwisata, ini yang selalu disosialisasikan oleh Pokdarwis kepada semua pengurus, pengelola, anggota, maupun pemilik dan pekerja di kios-kios pedagang. Sehingga nuansa keramahan akan terasa ketika pengunjung datang ke wisata pantai ini.

Kenangan. Untuk membuat kenangan yang baik tentang wisata Pantai Karang Jahe, Pokdarwis selalu mengembangkan inovasiinovasi baru dalam hal layanan, fasilitas bermain, maupun fasilitas umum. Semua aspek selalu dimonitor dan dikaji dalam forum yang dilakukan setiap bulannya, sehingga segala permasalahan dapat didiskusikan untuk menemukan solusi terbaik, dan ide-ide dapat ditampung untuk dapat direalisasikan jika memang ide itu dapat membuat Pantai Karang Jahe menjadi lebih baik dan diminati pengunjung.

Pengelolaan dari Pokdarwis Karang Jahe yang baik inilah yang mengantarkan Pantai Karang Jahe menjadi destinasi wisata unggulan di Kabupaten Rembang, kemudian disusul oleh Pantai Pasir Putih Wates yang juga dikelola oleh masyarakat dimana mengunggulkan hamparan pohon cemara dan pulau gedenya. Bahkan dalam skala regional, yaitu tingkat Jawa Tengah, Pantai Karang Jahe atau lebih dikenal dengan Karang Jahe Beach mendapatkan peringkat ke-7 sebagai destinasi wisata yang banyak dikunjungi oleh wisatawan pada tahun 2018. Sebagai informasi, Karang Jahe Beach mulai beroperasi dengan dikelola oleh Pokdarwis sejak tahun 2016. Dalam waktu 3 (tiga) tahun, Pokdarwis Karang Jahe Beach telah menunjukkan bahwa dengan pengelolaan yang baik maka dapat memberikan hasil pencapaian yang signifikan. Hal ini seyogyanya dapat memberikan motivasi dan inspirasi bagi Pokdarwis-Pokdarwis lainnya dalam mengembangkan destinasi wisata di daerahnya.

\section{Kendala Pengelolaan Destinasi Wisata Pantai melalui Pemberdayaan Masyarakat}

Dari sebagian besar narasumber yang meliputi pengurus Pokdarwis, pedagang kios yang tergabung dalam anggota Pokdarwis, hingga tokoh masyarakat setempat, yang meliputi Wisata Mangrove Tapak di Kota Semarang, Puri Maerokoco di Kota Semarang, Karang Jahe Beach di Kabupaten Rembang, Wisata Jembatan Merah Hutan Mangrove di Kabupaten Rembang, Pantai Pasir Kencana di Kota Pekalongan, Pantai Wonokerto di Kabupaten Pekalongan, Hutan Mangrove Mintaragen di Kota Tegal, Pantai Alam Indah di Kota Tegal, Pantai Muarareja Indah di Kota Tegal, dan Pantai Purwahamba Indah di Kabupaten Tegal mengatakan bahwa kendala utama pengelolaan dengan konsep pemberdayaan masyarakat ini adalah hanya sedikit masyarakat yang mau merintis destinasi wisata, atau hanya sedikit masyarakat yang mau bergabung dengan Pokdarwis. Karena pada awalnya, Pokdarwis ini sifatnya adalah sukarela sehingga masyarakat yang tergabung dalam Pokdarwis menyebut dirinya sebagai relawan.

Karakter masyarakat pesisir adalah mencari pekerjaan yang bisa cepat menghasilkan uang, sehingga banyak masyarakat yang lebih berminat untuk menjadi nelayan dari pada mengembangkan wisata pantainya. Baru kemudian setelah melihat hasil yang baik dalam pengelolaan wisata pantai, masyarakat baru berbondong-bondong untuk ikut serta berkontribusi dalam Pokdarwis.

Kendala yang kedua dalam hal pengelolaan, setelah 2 (dua) tahun pengelolaan, salah satu narasumber dari Pantai Pasir Kencana di Kota Pekalongan mengatakan bahwa ketika wisata pantai tersebut pertumbuhannya lambat, maka akan menurunkan semangat para anggota Pokdarwis sehingga banyak pengurus yang mencari pekerjaan sampingan, misalnya melaut, sehingga mempengaruhi kinerja Pokdarwis dan menjadi tidak fokus dalam pengelolaannya yang pada akhirnya mengakibatkan destinasi wisata menjadi tidak berkembang." 
Kendala selanjutnya, masih terkait dengan pengelolaan setelah 2 (dua) tahun, seperti yang disampaikan oleh salah satu narasumber dari Pantai Wonokerto di Kabupaten Pekalongan, bahwa ketika destinasi wisata telah memperlihatkan hasil yang bagus, maka banyak sekali pihak-pihak yang ingin mengambil bagian dalam pengelolaan tersebut. Misalnya dalam hal keamanan, ada banyak pihak di luar pedukuhan tempat destinasi wisata tersebut yang ingin berkontribusi dengan harapan dapat memperoleh keuntungan dari hasil pengelolaan wisatanya. Atau kebijakan dari Desa setempat untuk menarik dana lebih, dengan alasan pengembangan daerah di desa secara keseluruhan, artinya di luar dari pedukuhan tempat destinasi wisata pantai tersebut. Sedangkan, pedukuhan tersebut masih membutuhkan banyak dana untuk pengembangan pedukuhannya, karena mata pencaharian sebagai pengelola Pokdarwis maupun pedagang merupakan mata pencaharian utama selain nelayan. Belum lagi, adanya tawaran-tawaran mengenai investasi yang belum diketahui bentuk kerjasamanya oleh masyarakat setempat. Sehingga dikhawatirkan akan menggeser warga lokal dalam berwirausaha sebagai pedagang maupun sebagai pengelola Pokdarwis.

Kendala lainnya adalah masalah teknis dan operasional termasuk ego sektoral para pengelola atau anggota Pokdarwis, tetapi hal ini tidak menjadi masalah besar karena akan dapat dicarikan jalan terbaik melalui musyawarah di dalam forum yang diselenggarakan setiap 1 (satu) bulan hingga 3 (tiga) bulan sekali tergantung kebijakan dari masing-masing Pokdarwis. Tetapi ada juga destinasi wisata yang tidak memiliki forum musyawarah atau ada forum tetapi tidak ada tindak lanjut dari pengurus.

\section{Dukungan Pemerintah dan Dukungan Swasta}

Peran Pemerintah dalam hal ini Dinas Pariwisata sangat dirasakan dalam pengelolaan destinasi wisata di Karang Jahe Beach. Menurut salah satu narasumber di
Karang Jahe Beach, pendampingan dari Pemerintah dimulai dari awal pengelolaan Pokdarwis, pengadaan pelatihan-pelatihan SDM, pelatihan berwirausaha, pelatihan SAR, pendampingan di lapangan, pengadaan 11 ruko dan 7 gazebo, serta alat-alat outbound. Disamping itu, pemerintah juga membantu dalam hal promosi untuk memperkenalkan Karang Jahe Beach ke masyarakat luas sehingga dapat meningkatkan jumlah pengunjung, diantaranya dengan promosi melalui video, social media, membuat komunitas binaan, ikut serta dalam pameran-pameran baik skala lokal, regional, maupun nasional, dan membuat festival atau event untuk menarik pengunjung datang ke destinasi wisata.

Demikian halnya di Pantai Pasir Kencana Kota Pekalongan, Pemerintah membantu pembangunan jembatan, spot selfie, kios pedagang, joglo pertunjukan, MCK, dan lain sebagainya. Di Pantai Alam Indah Kota Tegal, Pantai Muarareja Indah Kota Tegal, dan Pantai Purwahamba Indah Kabupaten Tegal, Pemerintah juga membantu dalam pengembangan infrastruktur, dimana diketahui bahwa kondisi jalan di sebagian besar wilayah Pantai Utara Jawa Tengah yang menuju ke pantai masih kurang layak, sehingga upaya pemerintah adalah perbaikan jalan dan jembatan, kemudian pembangunan MCK, musholla, maupun fasilitas umum lainnya.

Tetapi, ada juga Pokdarwis di wilayah Pantai Utara Jawa Tengah yang hanya mendapatkan sedikit bantuan dari pemerintah, misalnya seperti informasi dari salah satu narasumber di Pantai Wonokerto Kabupaten Pekalongan bahwa pernah diberikan pelatihan tapi hanya sekali kemudian tidak ada lagi tindak lanjut atau monitoring. Bantuan dari pemerintah berupa suntikan dana untuk membangun destinasi wisata sama sekali tidak ada. Semua murni dari upaya masyarakat hingga masyarakat rela tidak mendapatkan penghasilan karena uang yang didapatkan dari tiket masuk itu digunakan untuk membuat fasilitas-fasilitas seperti pagar, 
tempat duduk pengunjung, area parkir, gazebo, kios-kios, dan lain sebagainya.

Mengenai dukungan swasta, salah satu contoh yang sudah berjalan adalah di pantai Karang Jahe di Kabupaten Rembang, yaitu PT Djarum telah ikut membantu penghijauan di wilayah ini. Hal ini merupakan salah satu program CSR (Corporate Social Responsibility) dari PT Djarum yang murni merupakan bentuk bakti sosial. Demikian pula di pantai Muarareja di Kabupaten Tegal, Provinsi Jawa Tengah dimana Pacific Paint memberikan bantuan pengecatan ke kios-kios pedagang agar kios tampak indah dan menarik. Kegiatan ini juga merupakan salah satu program CSR dari Pacific Paint. Kemudian juga ada pihak swasta yang membantu membuatkan spot selfie di pantai Muara Reja, Kabupaten Tegal.

Dari hasil observasi peneliti ke 3 (tiga) kabupaten dan 3 (tiga) kota di pesisir pantai utara Jawa Tengah, belum banyak destinasi wisata pantai yang mendapatkan dukungan swasta dalam bentuk CSR. Kerjasama dengan pihak swasta ini dirasakan adalah pengetahuan yang baru bagi banyak pengelola Pokdarwis yang peneliti temui. Adanya ketakutan-ketakutan bahwa nantinya pihak swasta akan meminta kompensasi dari bantuannya dan bahkan akan menggeser posisi pengelolaan masyarakat setempat menjadi issue yang cukup besar di kalangan Pokdarwis. Hal ini diperkuat juga dengan pengakuan salah satu narasumber bahwa ada perwakilan dari Bank BNI melalui pihak BUMDES yang mendatangi Pokdarwis dan mengatakan akan memberikan program CSR berupa membangun MCK dan fasilitas lainnya tetapi dengan syarat memberikan surat jaminan sertifikat tanah.

\section{Dampak Ekonomi Pengelolaan Destinasi Wisata melalui Pemberdayaan Masyarakat}

\section{Pendapatan Asli Daerah (PAD)}

Saragih (2003) menyatakan bahwa setiap terjadi perubahan kondisi perekonomian akan memberikan dampak berarti terhadap perubahan pendapatan asli daerah (PAD).
Daerah yang memiliki perekonomian yang baik, akan memiliki PAD yang tinggi. Dengan demikian dapat dikatakan bahwa semakin baik kondisi perekonomian suatu daerah akan menunjang terhadap peningkatan PAD. Sehingga dapat dikatakan pula bahwa perekonomian daerah berpengaruh secara positif terhadap PAD.

Pengertian PAD berdasarkan UndangUndang Nomor 33 Tahun 2004 yaitu pendapatan yang diperoleh daerah yang dipungut berdasarkan peraturan daerah sesuai dengan peraturan perundang-undangan. PAD merupakan pendapatan yang bersumber dari hasil pajak daerah, hasil retribusi daerah, hasil pengelolaan kekayaan daerah yang dipisahkan, dan lain-lain pendapatan asli daerah yang sah, yang bertujuan untuk memberikan keleluasaan kepada daerah dalam menggali pendanaan dalam pelaksanaan otonomi daerah dalam rangka mewujudkan asas desentralisasi. (Penjelasan UU No 33 Tahun 2004).

Menurut Sidik (2002) bahwa salah satu tujuan utama dari desentralisasi fiskal adalah terciptanya kemandirian daerah. Pemerintah daerah diharapkan mampu menggali sumbersumber keuangan lokal, khususnya melalui pendapatan asli daerah. Daerah yang memiliki tingkat pertumbuhan pendapatan asli daerah yang positif mempunyai kemungkinan memperbaiki kondisi perekonomian menjadi lebih baik.

Dari hasil wawancara peneliti ke narasumber di beberapa destinasi wisata yang penulis singgahi, destinasi-destinasi wisata tersebut sebagian besar baru dikelola dengan manajemen Pokdarwis yang baik sekitar 2 (dua) hingga 4 (empat) tahun terakhir. Seperti misalnya Karang Jahe Beach baru dikelola oleh Pokdarwis sejak tahun 2016. Kemudian Pantai Wonokerto baru dikelola oleh Pokdarwis pada tahun 2018, Pantai Muarareja dan Pantai Purwahamba sekitar tahun 2015, dan lain sebagainya. Perlu diketahui bahwa destinasi wisata pantai mulai dibuka untuk masyarakat ada yang sudah memiliki Pokdarwis, ada juga yang belum memiliki Pokdarwis. Sebelum tahun 
2015, bagi destinasi wisata pantai yang telah memiliki Pokdarwis, pengelolaan Pokdarwis masih dirasa kurang. Perbaikan demi perbaikan dilakukan oleh Pemerintah Daerah setempat dengan terus mendampingi
Pokdarwis di lapangan maupun memberikan pelatihan-pelatihan.

Tabel 1 di bawah ini menjelaskan tentang pendapatan asli daerah di sektor pariwisata untuk wilayah pantai utara Jawa Tengah dari tahun 2015 hingga tahun 2018.

Tabel 1. Pendapatan Asli Daerah dari Sektor Pariwisata di Wilayah Pantai Utara Jawa Tengah Tahun 2015 2018.

\begin{tabular}{|c|c|c|c|c|c|}
\hline \multirow[t]{3}{*}{ No } & \multirow[t]{3}{*}{ Kota/ Kab } & \multicolumn{4}{|c|}{ Pendapatan Asli Daerah di Sektor Pariwisata } \\
\hline & & 2015 & 2016 & 2017 & 2018 \\
\hline & & $\mathbf{R p}$ & $\mathbf{R p}$ & $\mathbf{R p}$ & $\mathbf{R p}$ \\
\hline 1 & Kab Brebes & 1.292 .006 .650 & 1.279 .481 .350 & 1.352 .260 .000 & 1.774 .194 .100 \\
\hline 2 & Kab Tegal & 4.481.614.800 & 4.037 .931 .845 & 3.802.474.200 & 7.594.384.240 \\
\hline 3 & Kota Tegal & 930.545 .200 & 561.190 .100 & 863.400 .000 & 1.616.111.175 \\
\hline 4 & Kab Pemalang & 2.137.317.000 & 2.059.805.700 & 2.961.228.600 & 3.240 .394 .700 \\
\hline 5 & Kab Pekalongan & 2.634.092.000 & 2.937 .600 .000 & 1.812.644.000 & 3.825.864.000 \\
\hline 6 & Kota Pekalongan & 1.081.989.250 & 827.888 .750 & 1.500 .669 .350 & 1.618 .103 .750 \\
\hline 7 & Kab Batang & 1.118 .909 .600 & 2.751 .268 .200 & 6.348 .240 .795 & 5.878 .540 .000 \\
\hline 8 & Kab Kendal & 133.208 .504 & 1.670 .460 .000 & 1.343.285.907 & 1.767 .831 .450 \\
\hline 9 & Kota Semarang & 18.157 .756 .234 & 18.656 .657 .836 & 29.076 .280 .548 & 30.351 .402 .985 \\
\hline 10 & Kab Demak & 1.351 .246 .000 & 1.355 .086 .000 & 1.661 .158 .125 & 1.689 .516 .000 \\
\hline 11 & Kab Jepara & 2.764 .942 .814 & 3.172 .623 .375 & 1.482 .425 .000 & 3.459 .014 .625 \\
\hline 12 & Kab Pati & 106.506.972 & 372.583 .000 & 375.535 .970 & 1.037 .410 .000 \\
\hline 13 & Kab Rembang & 1.407 .594 .550 & 2.199 .686 .462 & 2.034 .490 .603 & 2.409 .810 .000 \\
\hline & $\begin{array}{c}\text { otal PAD Sektor } \\
\text { Pariwisata }\end{array}$ & 37.597.729.574 & 41.882.262.618 & 54.614.093.098 & 66.262.577.025 \\
\hline
\end{tabular}

Sumber: Statistik Pariwisata Jawa Tengah Tahun 2015 - 2018

Dari tabel di atas, dapat diketahui bahwa secara keseluruhan, setiap tahunnya pendapatan asli daerah di sektor pariwisata terus meningkat. Pertumbuhan PAD pariwisata tersebut secara runtut adalah sebagai berikut: pada tahun 2016 terdapat peningkatan sebesar $11,40 \%$ dari PAD pariwisata tahun 2015; kemudian pada tahun 2017 terdapat peningkatan sebesar 30,40\% dari PAD pariwisata tahun 2016; dan pada tahun 2018 terdapat peningkatan sebesar $21,33 \%$ dari PAD pariwisata tahun 2017, seperti diilustrasikan oleh grafik gambar 7 di bawah ini.

\section{Tingkat Kunjungan Wisatawan}

Selain dilihat dari pendapatan asli daerah di bidang pariwisata, tingkat kunjungan wisatawan juga dapat menjadi acuan untuk melihat pertumbuhan pariwisata yang baik bagi suatu wilayah. Seperti dikemukakan oleh Syahadat (2006) dalam hasil penelitiannya yang menyatakan bahwa faktor pelayanan, sarana dan prasarana, obyek dan daya tarik wisata alam, dan keamanan secara bersama-sama (simultan) mempunyai pengaruh terhadap jumlah pengunjung. Demikian pula yang diungkapkan oleh Sihotang, Santoso, dan Iskandar (2015) yang menyatakan bahwa jumlah wisatawan yang berkunjung mempunyai pengaruh pada Pendapatan Asli Daerah melalui pajak hiburan, pajak hotel, dan restoran.

Jumlah kunjungan wisatawan nusantara di pesisir pantai utara Jawa Tengah seperti dijelaskan pada tabel 2 berikut ini. 
Tabel 2. Jumlah Kunjungan Wisatawan Nusantara dari Tahun 2014 - 2018

\begin{tabular}{llrrrrr}
\hline \multirow{2}{*}{ No } & Kota/ Kab & \multicolumn{5}{c}{ Jumlah Kunjungan Wisatawan Domestik/ Nusantara } \\
\cline { 3 - 7 } & & \multicolumn{1}{c}{$\mathbf{2 0 1 4}$} & \multicolumn{1}{c}{$\mathbf{2 0 1 5}$} & \multicolumn{1}{c}{$\mathbf{2 0 1 6}$} & \multicolumn{1}{c}{ 2017 } & \multicolumn{1}{c}{$\mathbf{2 0 1 8}$} \\
\cline { 3 - 7 } & & Pengunjung & Pengunjung & Pengunjung & Pengunjung & Pengunjung \\
\hline 1 & Kab Brebes & 292.928 & 413.102 & 477.395 & 333.999 & 473.996 \\
2 & Kab Tegal & 666.767 & 805.650 & 684.238 & 728.912 & 1.361 .855 \\
3 & Kota Tegal & 502.789 & 531.162 & 559.669 & 291.292 & 498.884 \\
4 & Kab Pemalang & 286.098 & 271.000 & 423.148 & 454.494 & 563.637 \\
5 & Kab Pekalongan & 259.659 & 379.011 & 371.478 & 323.800 & 543.271 \\
6 & Kota Pekalongan & 234.127 & 406.530 & 546.461 & 255.191 & 343.791 \\
7 & Kab Batang & 317.040 & 452.203 & 1.008 .632 & 545.057 & 582.904 \\
8 & Kab Kendal & 186.470 & 224.256 & 164.106 & 135.825 & 1.176 .643 \\
9 & Kota Semarang & 2.692 .104 & 2.853 .564 & 3.023 .441 & 4.198 .584 & 5.703 .282 \\
10 & Kab Demak & 1.431 .542 & 1.454 .556 & 1.526 .709 & 1.569 .917 & 1.618 .458 \\
11 & Kab Jepara & 1.485 .746 & 1.649 .663 & 1.753 .238 & 2.132 .073 & 2.556 .046 \\
12 & Kab Pati & 958.625 & 1.088 .341 & 1.247 .109 & 1.357 .237 & 1.246 .786 \\
13 & Kab Rembang & 392.389 & 1.395 .242 & 1.222 .448 & 987.193 & 1.530 .245 \\
TOTAL WISNUS & $\mathbf{9 . 7 0 6 . 2 8 4}$ & $\mathbf{1 1 . 9 2 4 . 2 8 0}$ & $\mathbf{1 3 . 0 0 8 . 0 7 2}$ & $\mathbf{1 3 . 3 1 3 . 5 7 4}$ & $\mathbf{1 8 . 1 9 9 . 7 9 8}$ \\
\hline
\end{tabular}

Sumber: Statistik Pariwisata Jawa Tengah Tahun 2014 - 2018

Dari tabel di atas, dapat diketahui bahwa terdapat peningkatan jumlah kunjungan wisatawan nusantara di wilayah pantai utara Jawa Tengah, dengan rincian sebagai berikut: terdapat peningkatan sebesar $22,85 \%$ jumlah kunjungan wisatawan nusantara pada tahun 2015 dari tahun sebelumnya 2014; selanjutnya peningkatan sebesar 9,09\% jumlah kunjungan wisatawan nusantara pada tahun 2016 dari tahun sebelumnya 2015; kemudian peningkatan sebesar $2,35 \%$ jumlah kunjungan wisatawan nusantara pada tahun 2017 dari tahun sebelumnya 2016; dan peningkatan sebesar $36,70 \%$ jumlah kunjungan wisatawan melonjak pada tahun 2018 dari tahun sebelumnya 2017, seperti diilustrasikan oleh grafik gambar 8 di bawah ini

\section{Pendapatan Per Kapita}

Purwanti dan Nugraheni (2001) menyatakan bahwa pengukuran kemajuan sebuah perekonomian dapat pula diukur dengan menggunakan Produk Domestik Bruto (PDB) dimana pada tingkat regional disebut Produk Domestik Regional Bruto (PDRB). PDRB merupakan jumlah barang dan jasa yang dihasilkan oleh suatu perekonomian dalam satu tahun dan dinyatakan dalam harga pasar. Untuk dapat mengukur pertumbuhan ekonomi yang lebih baik lagi dan lebih tepat mencerminkan kesejahteraan penduduk di suatu wilayah, maka digunakanlah Pendapatan Per Kapita Produk Domestik Bruto. Cara menghitungnya adalah dengan membagi PDB atau PDRB suatu wilayah dengan jumlah penduduk di wilayah tersebut, sehingga dapat disebut juga sebagai PDB atau PDRB rata-rata (Purwanti \& Nugraheni, 2001). 
Tabel 3. Pendapatan Per Kapita Wilayah Pantai Utara Jawa Tengah Tahun 2014 - 2018

\begin{tabular}{llrrrrr}
\hline \multirow{2}{*}{ No } & Wilayah Pantai Utara & \multicolumn{5}{c}{ Pendapatan per kapita disesuaikan (rupiah/orang/tahun) } \\
\cline { 3 - 7 } & \multicolumn{1}{c}{ Jawa Tengah } & $\mathbf{2 0 1 4}$ & $\mathbf{2 0 1 5}$ & $\mathbf{2 0 1 6}$ & $\mathbf{2 0 1 7}$ & \multicolumn{1}{c}{$\mathbf{2 0 1 8}$} \\
\hline 1 & Kabupaten Brebes & 8.783 .610 & 8.898 .000 & 9.148 .000 & 9.554 .000 & 9.890 .000 \\
2 & Kabupaten Tegal & 8.049 .700 & 8.367 .000 & 8.709 .000 & 9.136 .000 & 9.433 .000 \\
3 & Kota Tegal & 11.519 .210 & 11.748 .000 & 11.849 .000 & 12.283 .000 & 12.830 .000 \\
4 & Kabupaten Pemalang & 6.910 .760 & 7.177 .000 & 7.447 .000 & 7.785 .000 & 8.186 .000 \\
5 & Kabupaten Pekalongan & 8.937 .570 & 9.208 .000 & 9.300 .000 & 9.702 .000 & 10.221 .000 \\
6 & Kota Pekalongan & 11.006 .440 & 11.253 .000 & 11.721 .000 & 11.800 .000 & 12.312 .000 \\
7 & Kabupaten Batang & 8.011 .690 & 8.244 .000 & 8.568 .000 & 8.805 .000 & 9.203 .000 \\
8 & Kabupaten Kendal & 10.125 .640 & 10.419 .000 & 10.631 .000 & 10.863 .000 & 11.257 .000 \\
9 & Kota Semarang & 12.802 .480 & 13.589 .000 & 13.909 .000 & 14.334 .000 & 14.895 .000 \\
10 & Kabupaten Demak & 9.003 .500 & 9.118 .000 & 9.377 .000 & 9.544 .000 & 10.001 .000 \\
11 & Kabupaten Jepara & 9.194 .970 & 9.504 .000 & 9.695 .000 & 9.745 .000 & 10.169 .000 \\
12 & Kabupaten Pati & 9.106 .280 & 9.380 .000 & 9.548 .000 & 9.813 .000 & 10.190 .000 \\
13 & Kabupaten Rembang & 9.013 .010 & 9.122 .000 & 9.453 .000 & 9.736 .000 & 10.191 .000 \\
\hline
\end{tabular}

Sumber: Badan Pusat Statistik Jawa Tengah

Dari tabel 3 di atas, dapat diketahui bahwa rata-rata masyarakat wilayah Pantai Utara Jawa Tengah mengalami peningkatan pendapatan per kapita, dimana peningkatan yang cukup signifikan terjadi di Kabupaten Rembang, Kabupaten Pekalongan, dan Kota Tegal. Terdapat peningkatan sebesar 1,21\% pendapatan per kapita pada tahun 2015 dibandingkan tahun 2014; selanjutnya peningkatan sebesar $3,63 \%$ pendapatan per kapita tahun 2016 dibandingkan tahun 2015; kemudian peningkatan sebesar 2,99\% pendapatan per kapita tahun 2017 dibandingkan tahun 2016; dan lonjakan peningkatan sebesar $4,67 \%$ pendapatan per kapita tahun 2018 dibandingkan tahun 2017. Untuk Kabupaten Pekalongan, terdapat peningkatan sebesar $1,00 \%$ pendapatan per kapita tahun 2016 dibandingkan tahun 2015; kemudian peningkatan sebesar 4,32\% pendapatan per kapita tahun 2017 dibandingkan tahun 2016; dan peningkatan sebesar $5,35 \%$ pendapatan per kapita tahun 2018 dibandingkan tahun 2017. Selanjutnya untuk Kota Tegal, terdapat peningkatan sebesar $1,99 \%$ pendapatan per kapita pada tahun 2015 dibandingkan tahun 2014; selanjutnya peningkatan sebesar $0,86 \%$ pendapatan per kapita tahun 2016 dibandingkan tahun 2015; kemudian peningkatan sebesar $3,66 \%$ pendapatan per kapita tahun 2017 dibandingkan tahun 2016; dan lonjakan peningkatan sebesar $4,45 \%$ pendapatan per kapita tahun 2018 dibandingkan tahun 2017, seperti diilustrasikan oleh grafik gambar 9 di bawah ini

\section{Pendapatan Destinasi Wisata}

Selanjutnya, dilihat dari pendapatan destinasi wisata yang telah berhasil dikelola oleh Pokdarwis, menurut informasi dari narasumber Pokdarwis di Karangjahe Beach di Kabupaten Rembang adalah sebagai berikut: pada tahun 2015 dimana pantai Karang Jahe belum dikelola oleh Pokdarwis, pendapatan yang diperoleh belum terlihat, pemasukan hanya dari parkir yang dikelola oleh masyarakat setempat, dan tidak ada tiket masuk wisata, kemudian pada tahun 2016 setelah dibentuk kepengurusan Pokdarwis dan sistem pengelolaan yang baik oleh masyarakat, terdapat pendapatan sebesar Rp 881.290.000,00. Selanjutnya pada tahun 2017 pendapatan wisata Pantai Karang Jahe telah berhasil mencapai 1 milyar yaitu 
sebesar Rp 1.128.179.000,00 dan pada tahun 2018 pendapatan wisata Pantai Karang Jahe melonjak menjadi Rp 1.610.510.000,00.

Peningkatan pendapatan ini, merupakan hasil dari hasil pengelolaan destinasi wisata yang baik yang meliputi penerapan Sapta Pesona, pengelolaan kepemilikan kios pedagang, kreatifitas para pengelola Pokdarwis dalam menyajikan wahana wisata pantai dan hiburan bagi pengunjung, kebersihan dan keamanan destinasi wisata, dukungan dari pemerintah dan swasta, serta pengelolaan keuangan yang baik dan jelas.

Selanjutnya, salah satu narasumber pengelola Pokdarwis dari wisata Pantai Wonokerto Kabupaten Pekalongan juga mengungkapkan bahwa kemajuan wisata Pantai Wonokerto merupakan hasil dari pengelolaan wisata yang baik dari pengurus Pokdarwis dan masyarakat setempat, hal ini terbukti dengan pendapatan wisata pantai ini pada tahun 2018 mencapai Rp 1.000.000.000,00.

Menurut informasi dari narasumber di Pantai Wonokerto Kabupaten Pekalongan, salah satu bentuk nyata dari pengelolaan destinasi wisata oleh masyarakat adalah pengelolaan dalam hal keuangan. Jumlah pemasukan pendapatan, setiap akhir bulan akan dibagi dengan kriteria sebagai berikut: $35 \%$ untuk diberikan kepada pengurus Pokdarwis dan anggota, kemudian 5\% untuk pengembangan unit wisata, $20 \%$ untuk dana sosial, dan $40 \%$ terhitung sebagai pemasukan ke Desa setempat.

Pengembangan unit wisata yang dimaksudkan di sini adalah pengembangan alat-alat untuk menarik pengunjung, perawatan fasilitas, dan pengadaan fasilitas pendukung di unit wisata. Sedangkan dana sosial yang dimaksudkan adalah bantuan untuk membangun masjid di pedukuhan setempat, pembangunan/ pengecatan musholla, kebersihan lingkungan, pembangunan saluran air, dan lain sebagainya, sehingga warga masyarakat yang tidak bekerja di unit wisata tersebut pun dapat menikmati hasil dari pengembangan pariwisata.

\section{Penyerapan Tenaga Kerja}

Dampak selanjutnya dari segi penyerapan tenaga kerja. Seperti yang disampaikan oleh narasumber di destinasi wisata Pantai Karang Jahe Rembang, wisata Pantai Wonokerto Pekalongan, dan wisata Pantai Muara Reja Tegal, bahwa jumlah pedagang yang membuka kios antara 50 hingga 70 kios di unit wisata tersebut. Para pedagang itupun membutuhkan tenaga kerja rata-rata 2 karyawan setiap kiosnya, sehingga penyerapan tenaga kerja lokal cukup banyak dan warga lokal tidak perlu merantau untuk mendapatkan pekerjaan.

Dari hasil wawancara peneliti kepada semua Pokdarwis di 3 (tiga) Kota dan 3 (Kabupaten) di atas, dapat diketahui bahwa dampak pengelolaan wisata melalui Pokdarwis ini sangat dirasakan oleh masyarakat setempat, diantaranya adalah: penduduk lokal dapat membuka usaha Homestay maupun berjualan di kios-kios yang telah di sediakan. Kios-kios tersebut ada yang memang sebagai fasilitas bagi warga setempat yang berarti gratis, tetapi ada juga yang disewakan dengan biaya sewa yang terjangkau setiap tahunnya, hal ini merupakan kebijakan dari masing-masing Pokdarwis. Syarat untuk ikut berjualan di unit wisata tersebut adalah merupakan warga penduduk lokal dengan dibuktikan KTP dan Kartu Keluarga. Dengan memfasilitasi penduduk lokal berjualan, dan memanfaatkan tenaga kerja lokal sebagai pengurus pokdarwis, sebagai tukang parkir, penjaga wahana wisata, petugas kebersihan, petugas keamanan, petugas tiket masuk dan tiket keluar, hal ini dapat membantu pemerintah dalam upaya mengentaskan kemiskinan dan meningkatkan kemandirian masyarakat dengan berbagai kegiatan yang kreatif dan inovatif dalam menyongsong kehidupan yang lebih baik.

\section{SIMPULAN}

Keberhasilan dari pengelolaan destinasi wisata, khususnya wisata Pantai di Wilayah Pesisir Pantai Utara Jawa Tengah tidak lepas dari peran aktif Pokdarwis dalam mengelola destinasi wisata setempat di dukung oleh 
pemerintah, serta adanya peran swasta. Pokdarwis yang berhasil adalah Pokdarwis yang dapat menerapkan Sapta Pesona dalam mengelola destinasi wisatanya, yang meliputi: Aman, Tertib, Bersih, Sejuk, Indah, Ramah, dan Kenangan. Peran Pokdarwis ini meliputi semua aspek, yaitu pengelolaan operasional destinasi wisata, pengelolaan pedagang kios setempat, pengelolaan kebersihan lingkungan, pengelolaan keuangan yang baik, dan pengelolaan kerjasama antar masyarakat dan Desa.

Pengelolaan destinasi wisata oleh masyarakat tidak terlepas dari kendalakendala, diantaranya mengenai karakter dari masyarakat pesisir Pantai Utara Jawa Tengah yang lebih menghendaki pekerjaan yang bisa cepat menghasilkan uang, sedangkan untuk merintis Pokdarwis ini merupakan kegiatan sosial atau sukarela. Masyarakat pesisir kurang menerima perubahan yang tidak sesuai dengan keinginannya, sulit menerima sesuatu yang dianggap kurang menguntungkan secara langsung. Masyarakat pesisir lebih menyukai hasil yang terlihat secara langsung, tidak memerlukan proses yang panjang. Untuk menerima hal yang baru, masyarakat pesisir perlu melihat contoh keberhasilan yang nyata.

Upaya pemerintah yang diperlukan untuk mendukung gerakan pemberdayaan masyarakat ini diantaranya adalah melakukan pendampingan dari awal berdirinya Pokdarwis, hingga Pokdarwis sudah dapat berdiri sendiri, yaitu dengan memberikan pelatihan-pelatihan misalnya: pelatihan SDM, pelatihan berwirausaha, pelatihan SAR, pendampingan lapangan, dan lain sebagainya. Dalam hal pengadaan fasilitas, pemerintah juga hadir untuk membantu dalam hal infrastruktur yaitu pembangunan jalan dan jembatan menuju ke destinasi wisata, kemudian pembangunan MCK, gazebo, ruko-ruko atau kios pedagang, musholla, dan fasilitas umum lainnya.

Selanjutnya, pemerintah juga aktif dalam mempromosikan destinasi wisata di daerahnya, melalui video, social media, membuat komunitas binaan, ikut serta dalam pameran-pameran baik skala lokal, regional, maupun nasional, dan membuat festival atau event untuk menarik pengunjung datang ke destinasi wisata.

Upaya swasta untuk mendukung gerakan pemberdayaan masyarakat ini, yang telah dilakukan adalah adanya CSR (Corporate Social Responsibility) atau bakti sosial mengenai penghijauan, penanaman cemara laut, pengecatan kios-kios pedagang, pembangunan tempat spot selfie, pengadaan fasilitas publik, dan lain sebagainya.

Dampak ekonomi pengelolaan destinasi wisata melalui pemberdayaan masyarakat selain peningkatan pendapatan asli daerah dari sektor pariwisata, juga adanya penyerapan tenaga kerja dari masyarakat lokal, diantaranya adalah sebagai pengurus pokdarwis, sebagai tukang parkir, penjaga wahana wisata, petugas kebersihan, petugas keamanan, petugas tiket masuk dan tiket keluar, dan karyawan di kios-kios pedagang. Selain itu masyarakat juga diuntungkan dengan adanya ruang usaha bagi masyarakat lokal untuk berjualan, baik itu berjualan makanan, souvenir, maupun jasa misalnya jasa fotografi, jasa perahu wisata, penyewaan motor wisata, sepeda hias, kereta wisata, dan penyewaan tikar.

Masyarakat yang awalnya berprofesi sebagai nelayan yang biasanya menjual hasil tangkapan ikannya langsung ke Tempat Pelelangan Ikan (TPI) maka dapat mengolah makanannya dengan berbagai olahan dan menjajakannya di kios-kios pedagang di destinasi wisata dengan untung yang lebih besar. Bahkan di beberapa destinasi wisata pantai, juga telah dikembangkan beberapa Homestay dari masyarakat setempat untuk mendukung kegiatan pariwisata di daerahnya. Keberhasilan suatu destinasi wisata akan menimbulkan multiplayer effect bagi masyarakat setempat. Hal ini dapat membantu pemerintah dalam upaya mengentaskan kemiskinan dan meningkatkan kemandirian masyarakat.

Masih banyak Pokdarwis di wilayah Jawa Tengah khususnya di Pantai Utara Pulau Jawa Tengah yang memerlukan pembinaan 
terkait tugas, pokok, dan fungsi, serta kinerja Pokdarwis yang baik dan efektif, sehingga perlu peran serta pemerintah untuk memfasilitasi hal tersebut.

Perlu adanya keberlanjutan program pendampingan dan pelatihan-pelatihan kepada masyarakat maupun pengelola Pokdarwis (pelatihan SDM, pelatihan variasi produk, pelatihan pemasaran, pelatihan keuangan, dan lain-lain), serta monitoring kegiatan-kegiatan masyarakat dan kendalakendala di lapangan.

Perlu adanya sosialisasi tentang program CSR pihak swasta sehingga meminimalkan adanya miskomunikasi atau pemanfaatan dari oknum-oknum tertentu untuk mengambil keuntungan.

Meningkatkan promosi destinasi wisata melalui online dan offline, serta penyelenggaraan berbagai event dan keikutsertaan dalam pameran baik berskala lokal, nasional, maupun internasional.

\section{REFERENSI}

Adikampana, I. M. (2017). In Pariwisata Berbasis Masyarakat. Denpasar: Cakra Press.

Danim, S., \& Darwis. (2003). Metode Penelitian Kebidanan: Prosedur, Kebijakan, dan Etik. Jakarta: Penerbit Buku Kedokteran EGC.

Dewi, M. H. (2013). Pengembangan Desa Wisata Berbasis Partisipasi Masyarakat Lokal di Desa Wisata Jatiluwih Tabanan Bali. Kawistara UGM, Vol 3.

Djamil, M. (2011). Pengelolaan Sumber Daya Wilayah Pesisir dalam Perspektif Otonomi Daerah (Tinjauan Kota Bengkulu dan Kabupaten Bengkulu Selatan). Proceeding Book Simposium Nasional Ilmu Administrasi Negara Untuk Indonesia, (pp. hal 331 - 339).
Fatmasari, D. (2014). Analisis Sosial Ekonomi dan Budaya Masyarakat Pesisir Desa Waruduwur, Kecamatan Mundu, Kabupaten Cirebon. Al-Amwal Jurnal Kajian Ekonomi dan Perbankan Syari'ah IAIN Syekh Nurjati Cirebon, Vol 6 No. 1.

Fitriansah, H. (2012). Keberlanjutan Pengelolaan Lingkungan Pesisir Melalui Pemberdayaan Masyarakat di Desa Kwala Lama Kabupaten Serdang Bedagai. Jurnal Pembangunan Wilayah dan Kota, Vol 8 No 4, hal 360 - 370 .

Hadiwijoyo, S. S. (2012). Perencanaan Pariwisata Pedesaan Berbasis Masyarakat. Salatiga: Graha Ilmu.

Hiariey, L. S. (2013). Peran Serta Masyarakat Pemanfaat Pesisir dalam Pengelolaan Wilayah Peisir Teluk Ambon Dalam. Jurnal Matematika, Sains, dan Teknologi, Vol 14 No 1, hal $48-61$.

Iskandar. (2009). Metodologi Peneliian Kualitatif. Jakarta: Gaung Persada.

Jalan Nasional Rute 1. (2019). Retrieved from wikipedia: https://id.wikipedia.org/wiki/Jalan_Nas ional_Rute_1

Karim, S., Kusuma, B. J., \& Amalia, N. (2017). Tingkat Partisipasi Masyarakat dalam Mendukung Kepariwisataan Balikpapan: Kelompok Sadar Wisata (Pokdarwis). Jurnal Kepariwisataan dan Hospitalitas, Vol 1 No 2.

Manumono, D. (2008). Perubahan Perilaku Masyarakat Kawasan Pesisir Akibat Penurunan Pendapatan Sebagai Dampak Abrasi dan Rob di Kabupaten Demak. Dinamika Pembangunan 
Pertanian dan Perdesaan: Tantangan

dan Peluang bagi Peningkatan

Kesejahteraan Petani. Bogor: Pusat

Analisis Sosial Ekonmi dan Kebijakan

Pertanian. Departemen Pertanian.

Mardjoeki, H. (2012). Pemberdayaan

Masyarakat Pesisir Pantai Utara Daerah

Kabupaten Cirebon. Jurnal Ekonomi,

Vol 1 No 1, hal 52 - 57.

Noer, N. M. (2018, March 26). Retrieved

from www.kompasiana.com:

https://www.kompasiana.com/nawawi

mnoer/5ab89b56dd0fa868be7e2612/so

sial-ekonomi-masyarakat-

pesisir?page $=$ all

Pantiyasa, I. W. (2011). Pengembangan

Pariwisata Berbasis Masyarakat

(Community Based Tourism) dalam

Pemberdayaan Masyarakat: Studi

Kasus Di Desa Bedulu, Blah Batuh,

Gianyar. Jurnal Ilmiah Hospitality

Management, Vol 1 No 2.

Pemerintah Indonesia. (2004). Undang

Undang Nomor 33 Tahun 2004 tentang

Perimbangan Keuangan antara

Pemerintah Pusat dan Pemerintah

Daerah. Jakarta.

Pemerintah Indonesia. (2010). Rencana

Strategis Direktorat Jenderal

Pembangunan dan Pemberdayaan

Masyarakat Desa. Jakarta.

Pemerintah Indonesia. (2013). Peta Laut

DISHIDROS TNI AL. Jakarta.

Pemerintah Indonesia. (2015). Statistik

Pariwisata Jawa Tengah Tahun 2015.

Semarang.

Pemerintah Indonesia. (2016). Statistik

Pariwisata Jawa Tengah Tahun 2016.

Semarang.
Pemerintah Indonesia. (2017). Statistik

Pariwisata Jawa Tengah Tahun 2017.

Semarang.

Pemerintah Indonesia. (2018). Badan Pusat

Statistik Jawa Tengah Tahun 2015.

Semarang.

Pemerintah Indonesia. (2018). Statistik

Pariwisata Jawa Tengah Tahun 2018.

Semarang.

Prasiasa, D. P., \& Hermawan, H. (2012).

Pengembangan Wisata Bahari di

Indonesia. Jakarta: Pusat Penelitian dan

Pengembangan Kebijakan

Kepariwisataan.

Rusyidi, B., \& Fedryansah, M. (2018).

Pengembangan Pariwisata Berbasis

Masyarakat. Jurnal Pekerjaan Sosial,

Vol 1 No 3, hal 155 - 165.

Saragih, J. P. (2003). Desentralisasi Fiskal dan Keuangan Daerah dalam Otonomi. Bogor: Ghalia Indonesia.

Sidik, M. (2002). Perimbangan Keuangan Pusat dan Daerah Sebagai Pelaksanaan Desentralisasi Fiskal (Antara Teori dan Aplikasinya di Indonesia). Setahun Implementasi Kebijaksanaan Otonomi Daerah di Indonesia. Yogyakarta.

Sihotang, Y., Santoso, H. F., \& Iskandar, D. (2015). Kaitan Jumlah Wisatawan Terhadap Pendapatan Asli Daerah Provindi DKI Jakarta Tahun 2009 2013. Jurnal Riset Akuntansi, Vol 7 No 1.

Sipahelut, M. (2010). Analisis

Pemberdayaan Masyarakat Nelayan di Kecamatan Tobelo Kabupaten Halmahera Utara. Bogor: Tesis 
Sekolah Pascasarjana Institut Pertanian Bogor.

Syahadat, E. (2006). Faktor-Faktor Yang Mempengaruhi Kunjungan Wisatawan di Taman Nasional Gede Pangrango. Jurnal Penelitian Sosial dan Ekonomi Kehutanan.

Syarief, E. (2001). Pembangunan Kelautan dalam Konteks Pemberdayaan Masyarakat Pesisir. Majalah PP/Th 2001/Edisi-25.

Ticoalu, D. E., Reppie, E., \& Telleng, A. T. (2013). Analisis Kebijakan Pemberdayaan Masyarakat Perikanan Tangkap di Kota Manado. Jurnal Ilmu dan Teknologi Perikanan Tangkap, Vol 1 No 3, hal 76 - 80.

Tulungen, J. J. (2001). Program Pengelolaan Sumber Daya Wilayah Pesisir Terpadu dan Berbasis Masyarakat: Telaah Kasus di Kabupaten Minahasa, Sulawesi Utara. Prosiding Pelatihan Pengelolaan Wilayah Pesisir Terpadu.
Pusat Kajian Sumberdaya Pesisir dan Lautan. Institut Pertanian Bogor.

Widodo, S. (2011). Strategi Nafkah Berkelanjutan Bagi Rumah Tangga Miskin di Daerah Pesisir. Makara Sosial Humaniora, Vol 15 No 1, hal 1020.

Yoeti, O. A. (2008). Ekonomi Pariwisata: Introduksi, Informasi, dan Implementasi. Jakarta: Rineka Cipta.

\section{BIODATA PENULIS}

Rullyana Puspitaningrum Mamengko, saat ini bekerja sebagai Dosen Tetap PNS di Universitas Negeri Yogyakarta. Bidang kajian yang diminati adalah pariwisata, perhotelan, pemasaran, MICE, dan manajemen. Sinta Id: 6172226.

Erlina Daru Kuntari, saat ini bekerja sebagai Dosen Tetap di Akademi Pariwisata Buana Wisata Yogyakarta. Bidang kajian yang diminati adalah pariwisata, ekonomi, dan akuntansi. Sinta Id: 6694407. 